\title{
Teachers' classroom assessment and grading practices
}

\author{
Ida Ayu Made Sri Widiastuti ${ }^{1, *}$ \\ ${ }^{1}$ English Education Study Program, Mahasaraswati Denpasar University, Denpasar, Bali, Indonesia
}

\begin{abstract}
This study was conducted to investigate the teachers' classroom assessment and grading practices in Junior high schools in Bali. The participants of this study were professional junior high school teachers who were randomly selected as the sample of this study. In depth interviews and classroom observations were intensively conducted to the participants to collect the required data for the purpose of the present study. This study revealed that junior high school teachers made use of formative and summative assessment and employed several ways of grading practices. There were several factors affecting their classroom assessment and grading practices consisting of internal factors and external factors. The most prominent internal factor was the teacher's philosophy of teaching and learning and the main external factors were recognized as mandated statewide learning factors and high stakes tests, government polices, and parents. The findings indicated that junior high school teachers constantly make an effort to establish a reasonable balance between their teaching philosophy and the classroom environment reality. Thus it is recommended that junior high school teachers should review their assessment and grading practices and employ more appropriate assessment and grading practices.
\end{abstract}

Key words: Teachers, Classroom, Assessment, Grading, Practices

\section{Introduction}

Assessment is a key component of learning because it provides teachers and students the opportunity to meaningfully reflect how learning is best delivered. When students are able to know how their ability and how they are doing in a class, they will be able to determine whether or not they comprehend the learning material [5], [20, 29]. Teachers, on the other hands, are required to have comprehensive understanding on students' ability in order that they can decide the upcoming lessons.

In determining the students' achievement, teachers should be aware of various factors that may affect their grade. Teachers' strong educational principles and teachers' values and beliefs about teaching and learning also become considerations in doing grading decisionmaking $[13,24,28]$. Moreover, the reseason why assessment and grading practices are considered to a complex process that should be done by every teacher $[11],[14,28]$

Many studies have been conducted related to classroom assessment and grading practices which many researchers found that grading practices are very complex decisionmaking process influenced by internal and external factors, as studies conducted by [18],

* Corresponding author: idaayuwidia@unmas.ac.id 
$[10,5]$. The phenomenon of assessment discrepancy made most of the teachers found that assessment and grading practices are difficult things to do. Therefore during grading practices, according to [28], $[5,9]$, the teachers have to employ their critical and logical thinking to accommodate all affecting factors to balance all of those factors.

Understanding the phenomenon that the teachers still encountered problems in assessment and grading practices, and they were still in conflict with their own beliefs and their school policy, therefore, it is very important to study the assessment and grading practices in order to provide valuable contributions to the teachers and other stakeholders for the improvement of assessment and grading practices conducted by all junior high school teachers.

\section{Method}

\subsection{Research Design}

Qualitative research design was employed in this study. A qualitative design is a common design whithin social sciences. According to this research method, data is collected from the participant to be coded, analyzed to draw the geralization.

\subsection{Participants}

The data of this study were collected from 10 English teachers who were randomly selected from junior high school in Denpasar city during the first term of 2017-2018 education year. Random sampling method can be used so that every teacher is equal possibility in the population. The data were collected by the researcher by conducting in depth interviews and classroom observation. In depth interviews and classroom observation give higher reability of data for this study.

\subsection{Measures}

Triagulation system with comparative analysis was used to measure the realibilty of the data. To ensure all data were agulated correctly, the qualitive data about the teachers' assessment and grading practices were put together and arranged into written form. The transcripts of the data were then coded and condensed into some categories or themes. Each theme is then analyzed argumentatively based on the logical theorical basis and factual phenomena. By employing this measure, the data can be analyzed based on their categories and the result can be easily angulated with other data. Cross data angulation allows the researcher to reveal higher reliability findings.

\subsection{Procedure and Data Analysis}

In-depth interviews and classroom observation were conducted to get the data regarding to the types of assessment and grading practices which usually conducted by the teachers, and the factors influence the teachers' grading practices. Interview guide were the instruments used to collect the primary data, while informal conversation were conducted to clarify the supplementary information. Observation blank sheets were utilized to note down the required data of the obeservation. The data were then transcribed into written form. The transcripts of the data were coded and condensed into some categories (theme). Using codes, the deconstruction phase began based on categorizing recurring ideas and major 
themes. The categories data were analyzed descriptively and urgumentatively to obtain the research findings about teachers'assessment and grading practices.

\section{Findings}

\subsection{Types of assessment conducted by the teachers}

There are some types of assessments commonly used by the teachers in assessing the students, the following are some excerpts of interviews conducted to the teachers in this study :

"I conducted formative assessment to see whether or not my students understand the lesson at the end of every learning unit. I also administer a summative test at the end of every semester to give my students score for one semester"

"I usually give my students formative assessment and then I score my students work straightly. I use the students' exercise book as a test. I score the students and then I return their work as soon as possible "

"I always give summative assessment at the end of semester using multiple choice tests and some completion test. I design my own test by getting most of the items from the internet"

The data above showed that the teachers carried out two types of assessment to measure the students' learning achievement. Formative assessment is usually conducted at every end of one learning unit and summative assessment is conducted at the end of the semester.

\subsection{Grading practices conducted by the teachers}

Grading is considered as the most essential parts of assessment process in which a teacher is reguired to provide decision to the student' achivement in learning. The following are some excerpts of the interviews related to grading practices according to the teahers :

"I use different way of grading for different activities. If I use the same way of grading I will never be able to see the students' real ability "

"When I am due to grade the students' assignment, I do it straight away because it is not easy for me because it really depends on my mood and my time. Subjectivity often occurred because many things I should consider in "

According to the excerpt, the teachers in this study carried out several ways of grading which tends to be in different ways to suit their needs.

\subsection{Factors influence the teachers' grading practices}

There are two factors which influence the teachers' grading practice, those are internal and external factors.

\subsubsection{Internal Factors}

The following are the excerpts of the data concerning internal factors.

"I grade the students based on my own philosophy of teaching and learning. The students' assignments should grade properly because I believe that the assignments are 
very helpful for the students. I grade them based on my philosophy of teaching and learning. I believe that practice makes perfect or by practicing you will get a better result"

"I gave the students assignment to do and then I grade them in order they see their ability and they can make improvement and joining the upcoming learning process easier."

"For me assessment and grading can help the students improve their learning achievement because based on assessment result they know what part of material they have not yet understood".

The excerpts show that the teachers usually carry out grading practices by grading their students assignments to help the students understand their ability and to improve their students' learning.

\subsubsection{External Factors}

There are many external factors that may influence the teachers' assessment and grading practices.

"I prefer to use my own test which I have been designed according to the standard. It is easier for me to grade because the material are related to what taught.".

"I am free to choose whether I follow the school policy or not. It is up to how I interpret the policy. I feel my personal professional assessment and my own judgment are more appropriate for the students' grade and the students' achievement".

"I am still confused with the school policy and the grading practices. I felt I could not do the grading properly. That is why I just used my own ways in grading".

"I need to show the students' parents considerably comprehensive information on the students' grade to make their parent understand their children's ability"

The result of the interviews showed that the most influential external factors were in the form of statewide mandate testing and high stakes tests; regional grading polices, and parents. The teachers described that the continually tried to establish reasonable balance between their philosophy of teaching and learning and the classroom environment realities and external factors.

\section{Results and Discussion}

The interviews conducted to the teachers indicated that most teachers carried out formative assessment and a summative assessment. However, it was found that most teachers were lack of comprehension on the primary purposes of formative and summative assessments. Ideally, the result of the formative assessment was mainly utilized for the improvement of teaching and learning processes, that is why feedback is essentially important to be given to the students [5], [1, 19, 22]. Feedback actually leads the teachers for the improvement of teaching [6], [3,15, 25, 26].

The teachers in this study mainly develop their own grading practices depending on their professional ideology, education background, norms and experiences in grading the students' learning performance. Teachers ideally are competent in creating effective 
grading systems to correctly measure the students' learning achievement [5], [2,4, 22]. Moreover, teachers should have a strong policy understanding to avoid some negative effects from external factors which may influence their grading decision making [2], $[13,16]$.

The grading practices for most teachers are considered to be important to do appropriately because students need to know their real ability in order to be able to make progress in learning [4], [7, 8, 11]. Moreover, the interviews conducted to the teachers showed that teachers have varied responses on the factors that influence their grading practices. The teachers experienced difficulty in avoiding factors which may affect their grading. Those factors varied in their forms including internal and external factors [10], $[12,13,27]$.

The most important internal factor that appears to influence teacher decision making concerning classroom assessment and grading practices is the teacher's philosophy of teaching and learning. These factors resulted the various ways of grading undertaken by the teachers and the decision in the same time might be also different. There are five types of teacher beliefs and values were identified internal factors in grading, such as: philosophy of teaching/learning, pulling for students, accommodating individual differences, students' development, and students' engagement and motivation. These factors are considerably influential factors in grading, but they are essential factors to improve and engage the students in learning [18], [22, 28, 23, 29].

The most influential external factors were in the form of statewide mandate testing and high stakes tests, regional grading polices, and parents. The teachers described that the continually tried to establish reasonable balance between their philosophy of teaching and learning and the classroom environment realities and external factors [14], [19, 22, 28]. Many teachers focus on making sure that the students gain a good score in national test. This indicates that the teachers 'assessment and grading decision getting high pressure from external factors especially those related to statewide mandated testing. Teachers more likely to reflect their grading in order to be used to guide the students to be able to do the national test conducted by the government nationally [10], [3, 5, 9]. These factors are considered to be important for the school stakeholders including students, teachers, headmaster and parents [19], [6, 28]

In some cases external factors are still controllable because they indirectly influence the students. Those factors are mainly dealt with how the teachers decide the grading practices undertaken. In a simple explanation, they are outsiders and merely manifested on the teachers' decision rather than the students' attitude or behavior [10]. In this study, three major external factors were identified which may significantly influenced the teachers' assessment and grading practices: (1) externally mandated statewide learning standards, mostly multiple choice, high stakes tests, (2) regional policies, and (3) parents. Here are some excerpts of the interviews related to external factors.

The discussion above showed that teachers' assessment and grading practices are mostly influenced by internal and external factors. In conclusion, the junior high schools teachers tend to employ their own assessment and grading practices based on their belief, knowledge, education background, experiences, school policy, norms and assessment principles. The teachers also preferred conducting their own assessment policy rather than national policy.

\section{References}

1. Black, P., \& Wiliam, D. Assessment and classroom learning. Assessment in Education:Principles, Policy \& Practice, 5(1), 7-74, (1998). 
2. Brookhart, S. M. Teachers' grading practices: Meaning and values. Journal of Educational Measurement, 20, 123-142, (1993).

3. Brookhart, S. M. Teachers' grading: Practice and theory. Applied Measurement in Education, 7, 279-30, (1994).

4. Brookhart, S. M. Classroom assessment: tensions and intersections in theory and practice. Teachers College Record, 106, 429-458, (2004).

5. Brookhart, S. M., \& Durkin, D. T. Classroom assessment, student motivation, and chievement in high school social studies classes. Applied Measurement in Education, 16,27-54, (2003).

6. Cheng, L., Rogers, T., \& Hu, H. ESL/EFL instructors' classroom assessment practices: Purposes, methods and procedures. Language Testing, 21, 360-389, (2004).

7. Cheng, L., Rogers, T., \& Wang, X. (in press). Assessment purposes and procedures in ESL/EFL classrooms. Assessment \& Evaluation in Higher Education.

8. Cheng, L., \& Wang, X. Grading, Feedback, and Reporting in Esl/Efl Classrooms. Language Assessment Quarterly, 4(1), 85-107, (2007).

9. Cumming, A. ESL/EFL instructors' practices for writing assessment: Specific or general purposes? Language Testing, 18, 207-224, (2001).

10. Duncan, C.R \& Noonan, B. Factors Affecting Teachers' Grading and Assessment Practices. The Alberta Journal of Educational Research Vol. 53, No. 1, Spring 2007, 1-21, (2007).

11. Dyrness, R. \& Dyrness, A. Making the grade in middle school. Kappa Delta Pi Record, 44(3), 114-118, (2008).

12. Guskey, T. Are zeroes your ultimate weapon? Education Digest: Essential Readings Condensed for Quick Review, 70 (3), 31-35, (2004).

13. Guskey, T. "It Wasn't Fair!” Educators' recollections of their experiences as students with grading. Paper presented at the annual meeting of the American Educational Research Association, San Francisco, CA, (2006).

14. Guskey, T. Five obstacles to grading reform. Educational Leadership, 69(3), 17-21, (2011).

15. Kulik, J. A., \& Kulik, C. C. Timing of feedback and verbal learning. Review of EducationalResearch, 58, 79-97, (1988).

16. McMillan, J. H., \& Lawson, S. R. Secondary science teachers' classroom assessment and grading practices. Educational Measurement: Issues and Practice, 20, 20-32, (2001).

17. McMillan, J. H., Myran, S., \& Workman, D. Elementary teachers' classroom assessment and grading practices. Journal of Educational Research, 95, 203-213, (2002).

18. McMillan, J. H., \& Workman, D. Classroom assessment and grading practices: A review of literature. Richmond, VA: Metropolitan Educational Research Consortium, Virginia Commonwealth University. (ERIC Document Reproduction Service No. ED453263), (1998).

19. McMillan, J. Assessment essentials for standards-based education (2) Thousand Oaks, CA: Sage Publications, (2008).

20. McMillan, J., \& Nash, S. Teacher classroom assessment and grading practices decision making. Paper presented at the annual meeting of the National Council on Measurement in Education, New Orleans, LA, (2000).

21. McMillan, J. H. \& Schumacher, S. Research in education: A conceptual introduction. New York: Longman, (2006).

22. Moeller, A. J., \& Reschke, C. A second look at grading and classroom performance:Report of a research study. The Modern Language Journal, 77, 163-169, (1993). 
23. Patton, M. Q. Qualitative research and evaluation methods (3rd Ed.). Thousand Oaks, CA: Sage, (2002).

24. Randall, J., \& Engelhard, G. Examining teacher grades using Rasch measurement theory. Journal of Educational Measurement, 46(1), 1-18, (2009).

25. Sri Widiastuti, I.A.Md. EFL Teachers' Beliefs and Practices of Formative Assessment to Promote Active Learning. The ASIAN EFL Journal. Volume 3, (2016).

26. Sri Widiastuti, I.A.Md. Teachers' Understanding of Formative Assessment. Jurnal Bahasa dan Seni. Vol 45, No 1 Juni, (2017).

27. Stiggins, R. J., Frisbie, D. A., \& Griswold, P. A. Inside high school: Building a research agenda. Educational Measurement: Issues and Practice, 8, 5-14, (1989).

28. Sun, Y \& Cheng, L. Teachers' grading practices: meaning and values assigned. Assessment in Education: Principles, Policy \& Practice, 21:3, 326-343, DOI: 10.1080/0969594X.2013.768207, (2014).

29. Wormeli, R. Accountability: Teaching through assessment and feedback, not grading. American Secondary Education, 34(3), 14-27, (2006). 